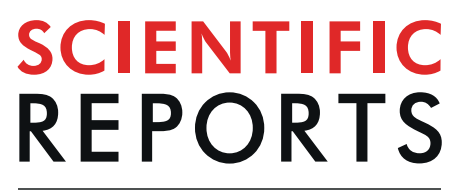

natureresearch

\title{
Dietary supplemental plant oils reduce methanogenesis from anaerobic microbial fermentation in the rumen
}

\author{
Julio Ernesto Vargas ${ }^{1,2}$, Sonia Andrés ${ }^{1}$, Lorena López-Ferreras ${ }^{1,3}$, Timothy J. Snelling $\mathbb{C}^{4,5}$, \\ David R. Yáñez-Ruíz ${ }^{6}$, Carlos García-Estrada7 \& Secundino López $\mathbb{B}^{1 *}$
}

Ruminants contribute to the emissions of greenhouse gases, in particular methane, due to the microbial anaerobic fermentation of feed in the rumen. The rumen simulation technique was used to investigate the effects of the addition of different supplemental plant oils to a high concentrate diet on ruminal fermentation and microbial community composition. The control (CTR) diet was a high-concentrate total mixed ration with no supplemental oil. The other experimental diets were supplemented with olive (OLV), sunflower (SFL) or linseed (LNS) oils at 6\%. Rumen digesta was used to inoculate the fermenters, and four fermentation units were used per treatment. Fermentation end-products, extent of feed degradation and composition of the microbial community (qPCR) in digesta were determined. Compared with the CTR diet, the addition of plant oils had no significant $(P>0.05)$ effect on ruminal $\mathrm{pH}$, substrate degradation, total volatile fatty acids or microbial protein synthesis. Gas production from the fermentation of starch or cellulose were decreased by oil supplementation. Methane production was reduced by $21-28 \%(P<0.001)$, propionate production was increased $(P<0.01)$, and butyrate and ammonia outputs and the acetate to propionate ratio were decreased $(P<0.001)$ with oilsupplemented diets. Addition of $6 \% \mathrm{OLV}$ and LNS reduced $(P<0.05)$ copy numbers of total bacteria relative to the control. In conclusion, the supplementation of ruminant diets with plant oils, in particular from sunflower or linseed, causes some favorable effects on the fermentation processes. The addition of vegetable oils to ruminant mixed rations will reduce methane production increasing the formation of propionic acid without affecting the digestion of feed in the rumen. Adding vegetable fats to ruminant diets seems to be a suitable approach to decrease methane emissions, a relevant cleaner effect that may contribute to alleviate the environmental impact of ruminant production.

Ruminant herbivory is characterized by foregut microbial anaerobic fermentation of structural carbohydrates from fibrous plant-based feedstuffs providing nutrients for the animal ${ }^{1}$. Moreover, ruminal microbes break down all components of the diet, with characteristic pathways involved in the degradation of fiber and non-structural carbohydrates, proteins and lipids ${ }^{2,3}$.

Ruminal fermentation can be considered beneficial in many aspects, but has also impacts on the environment. One of the global environmental impacts of livestock agriculture is the release of greenhouse gases (GHG) into the atmosphere ${ }^{4,5}$, in particular methane, a gas responsible for $20 \%$ of the global warming produced by all $\mathrm{GHG}^{6,7}$. It is estimated that raising farm animals accounts for about $16 \%$ of anthropogenic GHG emissions, with two-thirds of the total livestock GHG emissions produced by ruminants. Methane $\left(\mathrm{CH}_{4}\right)$ is produced in

${ }^{1}$ Instituto de Ganadería de Montaña (CSIC-Universidad de León), Departamento de Producción Animal, Universidad de León, E-24007, León, Spain. 'Universidad de Caldas, Facultad de Ciencias Agropecuarias, Grupo CIENVET, Manizales, Colombia. ${ }^{3}$ Department of Physiology/Metabolic Physiology, Institute of Neuroscience and Physiology, The Sahlgrenska Academy, University of Gothenburg, Medicinaregatan 11, PO Box 434, SE-405 30, Gothenburg, Sweden. ${ }^{4}$ Animal Production, Welfare and Veterinary Sciences, Harper Adams University, Edgmond, Shropshire, TF10 8NB, UK. ${ }^{5}$ The Rowett Institute, University of Aberdeen, Foresterhill, Aberdeen, AB25 2ZD, UK. ${ }^{6}$ Estación Experimental del Zaidín, CSIC, 18008, Granada, Spain. ${ }^{7}$ INBIOTEC, Instituto de Biotecnología de León, Avda. Real no. 1, Parque Científico de León, 24006, León, Spain. *email: s.lopez@unileon.es 
the rumen by the methanogens, archaea microbes that are closely associated with bacterial and ciliate protozoal $\mathrm{H}_{2}$-producing species ${ }^{8,9}$. The amount of methane emitted is strongly related to feed intake and diet composition. Thus, reductions in GHG from ruminants of up to $60 \%$ can be achieved just by dietary intervention, with a number of nutritional strategies proposed to reduce methane emissions ${ }^{10-12}$. One of these strategies is the supplementation of feed with plant oils ${ }^{13-15}$.

High-concentrate total mixed rations are provided to ruminants to achieve increased production, and it is becoming common practice to add fats as a concentrate source into ruminant diets to increase the energy density of the ration. Given the multiple and complex interactions between rumen microbes and diet ${ }^{1}$, dietary oil supplements may cause changes in the microbial community and thus fermentation processes in the rumen. The inclusion of fats in ruminant diets is considered a promising approach to manipulate the rumen microbial community to reduce methane emissions ${ }^{9,16-18}$. Reduction of methane production is a result of direct effects on the growth of these microbes ${ }^{19}$ or the metabolism pathways involved in methanogenesis ${ }^{12,20}$.

However, adding fats or oils to the ration ruminant diets can have other effects on rumen microbiota and fermentation. Oil supplements can affect the microbial community by a toxic effect as is the case for species of Gram-positive bacteria and ciliate protozoa ${ }^{21,22}$, or limit the microbial colonization of feed particles and the access of microbial enzymes to the substrates ${ }^{23,24}$. Consequently, feed digestion (ruminal and total tract) may be adversely affected by the addition of lipids ${ }^{23,25-28}$.

There are some studies on the effects of dietary plant oil supplementation on specific rumen parameters; but there is a paucity of work considering both the effects on the metabolic products and the likely microbial mechanisms that drive them, integrating these phenomena as a whole ${ }^{1,29}$. Most of these studies have focused on the dietary inclusion of oils rich in polyunsaturated fatty acids (mostly soybean, linseed, fish or algal oils) ${ }^{16-18}$. However, only a few compare the effects of oils with contrasting fatty acid composition (differing in the proportions of oleic, linoleic and $\alpha$-linolenic acids) on methane production and feed digestion in the rumen. Therefore, the objective of the study reported here was to examine the effects of vegetable oils with different fatty acid composition on rumen fermentation end-products and key members of the rumen microbiota. Special attention will be paid to the effects on methane production, to assess the potential of dietary supplementation with plant oils to mitigate environmental pollution by biogas derived from enteric fermentation in the rumen. An in vitro rumen simulation technique $\left(\right.$ RUSITEC $^{30}$ ) was used for a precise control of the fermentation conditions and the simultaneous measurement ${ }^{31,32}$ of digestibility, fermentation end-products, methane production, microbial protein synthesis, and key microbial groups.

\section{Results}

The composition of the four experimental diets is shown in Table 1. The control diet (CTR) was a high-concentrate (forage was less than $30 \%$, with $231 \mathrm{~g}$ neutral detergent fiber $/ \mathrm{kg}$ dry matter) total mixed ration formulated for high-yielding dairy ewes during lactation ( $153 \mathrm{~g}$ crude protein and $519 \mathrm{~g}$ non-structural carbohydrates/kg dry matter). In the supplemented diets, $6 \mathrm{~g}$ of olive (OLV), sunflower (SFL) or linseed (LNS) oil were added to $100 \mathrm{~g}$ of the control diet. There were no significant differences among diets $(P>0.05)$ in ruminal $\mathrm{pH}$. Compared with the CTR, the addition of oils had no apparent effect on substrate disappearance from the nylon bags containing the incubated diet. Organic matter, neutral detergent fiber and protein digestibility were higher with LNS than with SFL diet. Methane (total daily output in $\mathrm{mL} /$ day, or expressed relative to total gas of fermentation or per gram of fermentable organic matter) was quantitatively reduced $(P<0.001)$ when oil supplements were added to the CTR diet (Table 2). There were no significant differences $(P>0.05)$ between the type of oil in the extent to which methane production was reduced. Total volatile fatty acid (VFA) production was not affected $(P>0.05)$ by the addition of oils to the diet, but significant effects of oil supplementation on the production of specific VFA were noticed. Thus, the production of butyrate was decreased $(P=0.005)$ when any oil was added to the diet (Table 2$)$ and propionate and isoacids were significantly increased $(P<0.05)$ in LNS compared with the CTR diet. As a result, the acetate to propionate ratio in rumen digesta was significantly $(P<0.001)$ reduced in response to the addition of all vegetable oil treatments (Table 2$)$, with no differences $(P>0.05)$ in this ratio among the three supplemental oils. Although ammonia production was significantly $(P<0.05)$ reduced when an oil was added to the diet, microbial protein synthesis appeared to be unaffected (Table 2$)$.

Fermentation kinetics (gas production after $24 \mathrm{~h}$ incubation, rate of fermentation) were reduced when either starch or cellulose were incubated in LNS compared to CTR inocula (Table 3). In general, the gas production derived from the fermentation of starch or cellulose was significantly reduced when the substrates were incubated with ruminal inocula from fermenters fed with oil-supplemented diets (Table 3). Fractional fermentation rate of starch and gas production after $24 \mathrm{~h}$ of incubation of starch were decreased $(P \leq 0.001)$ by the three supplemental oils. Similarly, the volume of gas production at $24 \mathrm{~h}$ of incubation of cellulose and the average fermentation rate of cellulose in batch cultures were decreased $(P \leq 0.001)$ when liquid contents from RUSITEC vessels supplemented with an oil were used as inoculum.

Relative to the control diet, copy number of total bacteria (Fig. 1) was significantly reduced by the addition of either OLV $(P<0.001)$ or LNS oil $(P=0.044)$. The same inclusion level of SFL led to a non-significant $(P=0.095)$ reduction. The addition of oils did not affect significantly the copy number of ciliate protozoa $(P=0.98)$, fungi $(P=0.74)$ or methanogen $m c r A(P=0.66)$ in RUSITEC digesta (Fig. 1$)$. There were no significant $(P=0.61)$ differences among control and oil-supplemented diets in the copy number of Fibrobacter succinogenes, one of the main fibrolytic bacteria species.

\section{Discussion}

The study reported herein used a tested in vitro technology to simulate the effects of supplementing a high-concentrate diet with different vegetable oils, which varied in fatty acid composition, on ruminal fermentation and microbial community composition. The study was designed to measure diverse aspects of rumen metabolism using simultaneous measurements, including nutrient digestion, methane production and changes 


\begin{tabular}{|c|c|c|c|c|}
\hline Treatment & Control & $\begin{array}{l}\text { Olive } \\
\text { Oil }\end{array}$ & $\begin{array}{l}\text { Sunflower } \\
\text { Oil }\end{array}$ & $\begin{array}{l}\text { Linseed } \\
\text { Oil }\end{array}$ \\
\hline \multicolumn{5}{|c|}{ Ingredients (g/kg dry matter) } \\
\hline Cracked corn grain & 250 & 238 & 238 & 238 \\
\hline Barley grain & 150 & 143 & 143 & 143 \\
\hline Soybean meal & 200 & 190 & 190 & 190 \\
\hline Lucerne hay & 200 & 190 & 190 & 190 \\
\hline Beet pulp & 90 & 86 & 86 & 86 \\
\hline Molasses & 60 & 57 & 57 & 57 \\
\hline Sodium bicarbonate & 15 & 14 & 14 & 14 \\
\hline Mineral vitamin premix & 35 & 33 & 33 & 33 \\
\hline Olive oil & - & 60 & - & - \\
\hline Sunflower oil & - & - & 60 & - \\
\hline Linseed oil & - & - & - & 60 \\
\hline \multicolumn{5}{|c|}{ Composition (g/kg dry matter) } \\
\hline Organic matter & 925 & 927 & 930 & 929 \\
\hline Crude protein & 153 & 145 & 145 & 147 \\
\hline Neutral detergent fiber & 231 & 220 & 222 & 219 \\
\hline Acid detergent fiber & 115 & 109 & 110 & 108 \\
\hline Ether extract & 22 & 70 & 73 & 71 \\
\hline \multicolumn{5}{|c|}{ Dietary fatty acid profile (as \% of total fatty acids) } \\
\hline $\mathrm{C} 14: 0$ & 0.10 & - & 0.02 & - \\
\hline $\mathrm{C} 16: 0$ & 22.1 & 15.3 & 12.3 & 11.1 \\
\hline Total C18 & 76.9 & 82.1 & 85.2 & 87.4 \\
\hline \multicolumn{5}{|c|}{ Dietary C18 fatty acids (as \% of total C18 fatty acids) } \\
\hline C18:0 & 5.1 & 5.1 & 5.7 & 5.1 \\
\hline $\mathrm{C} 18: 1 c 9$ & 35.1 & 71.0 & 38.7 & 25.3 \\
\hline $\mathrm{C} 18: 2 c 9 c 12$ & 52.8 & 20.7 & 53.2 & 30.1 \\
\hline $\mathrm{C} 18: 3 c 9 c 12 c 15$ & 7.0 & 3.3 & 2.2 & 39.5 \\
\hline
\end{tabular}

Table 1. Ingredients and chemical composition of control and oil supplemented diets. Fatty acid profile of oils (as \% of total fatty acids). Olive oil: 12.7\% C16:0. 4.2\% C18:0. 71.2\% C18:1 c9. 7.0\% C18:2 c9c12. 1.6\% C18:3 c9c12c15. Sunflower oil: 8.5\% C16:0. 4.9\% C18:0. 35.4\% C18:1 c9. 47.8\% C18:2 c9c12. 0.3\% C18:3 c9c12c15. Linseed oil: $6.9 \%$ C16:0. 4.6\% C18:0. 19.7\% C18:1 $c 9.19 .6 \%$ C18:2 $c 9 c 12.47 .5 \%$ C18:3 $c 9 c 12 c 15$.

in the microbiota in the digesta. A number of previous studies have reporting results on the effects of lipid supplementation on some parameters of rumen fermentation, however, there are very few that address all these aspects joint- and simultaneously. Obtaining in vivo digesta samples can be challenging and require invasive procedures or surgery. However, the rumen simulation technique (RUSITEC) is an effective tool to characterize ruminal fermentation in vitro and allows precise control of culture conditions and of the inputs and outputs in each fermentation unit. In vitro systems for continuous culture of mixed rumen microorganisms contribute to reduce the use of experimental animals, and have been used previously to investigate effects of lipid supplementation ${ }^{31}$.

Supplementary fat increases the energy concentration of the diet but may also affect microbial fermentation and feed degradation in the rumen ${ }^{27}$. Supplementary lipids are associated with inhibition of the rumen microbiota or a physical coating of feed particles limiting their comminution and degradation ${ }^{21}$. However, nutrient degradation (organic matter or fiber) was not apparently affected when measured as substrate disappearance from feed containers (artificial fiber bags) in the RUSITEC fermenters. Furthermore, other parameters related to the extent of feed degradation in the rumen, such as fermentation gas or VFA production, were not affected by the addition of oils to the diet, indicating that effects of oil supplementation at $6 \%$ on feed digestibility would be of little biological relevance. The effects of lipids on rumen fermentation become more evident when purified substrates are fermented ${ }^{24}$, and affect mainly fiber degradation in the rumen ${ }^{23}$, with minor effects on the digestion of non-structural carbohydrates or protein ${ }^{26}$. It is worth mentioning that the amount and type of lipid added ${ }^{23,33}$ and the diet composition ${ }^{33,34}$ will determine the magnitude of the effects of dietary lipid supplementation on nutrient degradation. Our results are comparable to those reported by other authors showing minor effects of supplemental fats on extent of ruminal fermentation ${ }^{35,36}$. Doreau et al.$^{37}$ found that the dietary addition of oils at levels similar to that used in our study did not affect organic matter fermentation in the rumen. In a pooled analysis of a number of published studies, Hess et al. ${ }^{38}$ concluded that fats can be added to high-concentrate diets up to $6 \%$ with no effects on feed digestibility. Other meta-analysis showed that total tract and ruminal fiber digestibility were not affected by the supplementation of dairy cow diets with fats ${ }^{28}$. Patra ${ }^{39}$ concluded that fat had to be added to sheep diets at high concentrations to affect fiber digestibility adversely based on the available information, and Knapp et al. ${ }^{14}$ recommended levels of addition of fats to total mixed rations of up to 6-7\%.

Plant oils added to feed can also cause changes in the ruminal microbiota. In our study, total viable bacteria numbers were significantly reduced. Rumen bacteria can be hindered by dietary fats and oils as shown in studies 


\begin{tabular}{|c|c|c|c|c|c|c|c|}
\hline Item & $\begin{array}{l}\text { Control } \\
\text { (CTR) }\end{array}$ & $\begin{array}{l}\text { Olive oil } \\
\text { (OLV) }\end{array}$ & $\begin{array}{l}\text { Sunflower } \\
\text { oil (SFL) }\end{array}$ & $\begin{array}{l}\text { Linseed } \\
\text { oil (LNS) }\end{array}$ & $\begin{array}{l}\text { SEM } \\
(n=4)\end{array}$ & $P$ value & $\begin{array}{l}P \text { value contrast } \\
\text { CTR vs OIL }\end{array}$ \\
\hline Effluent, $\mathrm{mL} / \mathrm{d}$ & 577 & 565 & 513 & 569 & 10.1 & 0.164 & 0.255 \\
\hline $\mathrm{pH}$ & 6.73 & 6.72 & 6.66 & 6.67 & 0.012 & 0.126 & 0.126 \\
\hline \multicolumn{8}{|c|}{ Disappearance coefficients, $\mathrm{g}$ digested/100 $\mathrm{g}$ incubated } \\
\hline Organic matter & $67.4^{\mathrm{ab}}$ & $70.8^{\mathrm{ab}}$ & $66.1^{\mathrm{b}}$ & $72.1^{\mathrm{a}}$ & 1.27 & 0.022 & 0.172 \\
\hline Neutral detergent fiber & $32.9^{\mathrm{ab}}$ & $34.7^{\mathrm{a}}$ & $29.0^{\mathrm{b}}$ & $35.4^{\mathrm{a}}$ & 1.31 & 0.044 & 0.961 \\
\hline Acid detergent fiber & 23.4 & 24.3 & 19.7 & 26.9 & 1.58 & 0.082 & 0.879 \\
\hline Crude protein & $49.5^{\mathrm{ab}}$ & $54.9^{\mathrm{a}}$ & $47.6^{\mathrm{b}}$ & $54.7^{\mathrm{a}}$ & 1.83 & 0.036 & 0.197 \\
\hline \multicolumn{8}{|l|}{ Fermentation gas production } \\
\hline Total gas, $\mathrm{L} / \mathrm{d}$ & 3.01 & 2.75 & 2.81 & 2.98 & 0.066 & 0.470 & $<0.001$ \\
\hline Methane, $\mathrm{mL} / 100 \mathrm{~mL}$ total gas & $7.04^{\mathrm{a}}$ & $5.79^{\mathrm{b}}$ & $5.66^{\mathrm{b}}$ & $5.57^{\mathrm{b}}$ & 0.108 & 0.002 & $<0.001$ \\
\hline Methane, $\mathrm{mL} / \mathrm{d}$ & $212^{\mathrm{a}}$ & $160^{\mathrm{b}}$ & $162^{\mathrm{b}}$ & $166^{\mathrm{b}}$ & 12.5 & 0.040 & 0.006 \\
\hline Methane, $\mathrm{mmol} / \mathrm{g}$ fermentable OM & $1.02^{\mathrm{a}}$ & $0.81^{\mathrm{b}}$ & $0.78^{b}$ & $0.73^{\mathrm{b}}$ & 0.045 & 0.005 & $<0.001$ \\
\hline \multicolumn{8}{|l|}{ Volatile fatty acid (VFA, mmol/d) } \\
\hline Acetate & 24.9 & 23.8 & 22.0 & 24.1 & 0.455 & 0.206 & 0.160 \\
\hline Propionate & $8.39^{\mathrm{b}}$ & $10.30^{\mathrm{ab}}$ & $9.87^{\mathrm{ab}}$ & $11.88^{\mathrm{a}}$ & 0.342 & 0.003 & 0.002 \\
\hline Butyrate & $7.38^{\mathrm{a}}$ & $5.64^{\mathrm{b}}$ & $5.50^{\mathrm{b}}$ & $5.51^{\mathrm{b}}$ & 0.166 & 0.005 & $<0.001$ \\
\hline Isoacids & $2.03^{\mathrm{b}}$ & $2.20^{\mathrm{ab}}$ & $2.13^{\mathrm{ab}}$ & $2.52^{\mathrm{a}}$ & 0.055 & 0.045 & 0.070 \\
\hline Total VFA & 51.2 & 48.5 & 46.2 & 50.7 & 0.715 & 0.109 & 0.125 \\
\hline Acetate:propionate ratio & $2.99^{\mathrm{a}}$ & $2.32^{\mathrm{b}}$ & $2.27^{\mathrm{b}}$ & $2.03^{\mathrm{b}}$ & 0.046 & $<0.001$ & $<0.001$ \\
\hline Ammonia $\mathrm{N}, \mathrm{mg} / \mathrm{d}$ & $89.1^{\mathrm{a}}$ & $72.4^{\mathrm{b}}$ & $65.0^{\mathrm{b}}$ & $65.0^{\mathrm{b}}$ & 1.58 & 0.001 & $<0.001$ \\
\hline Microbial protein, g/d & 1.06 & 1.02 & 0.90 & 1.14 & 0.046 & 0.353 & 0.714 \\
\hline Microbial protein, $\mathrm{g} / 100 \mathrm{~g}$ fermentable OM & 11.4 & 9.2 & 9.6 & 11.2 & 0.72 & 0.158 & 0.127 \\
\hline
\end{tabular}

Table 2. Effects of oils added to the diet on ruminal fermentation in RUSITEC fermenters. CTR $=$ Control diet; $\mathrm{OLV}=$ control diet supplemented with $6 \%$ olive oil; SFL $=$ control diet supplemented with $6 \%$ sunflower oil; LNS $=$ control diet supplemented with $6 \%$ linseed oil. SEM $=$ standard error of the mean; $\mathrm{OM}=$ organic matter. Contrast CTR vs OIL: comparison between CTR and all treatments supplemented with oil. ${ }^{\mathrm{a}, \mathrm{b}}$ Within a row, mean values without common superscript letters differ $(P<0.05)$.

in vivo ${ }^{40,41}$ and in pure cultures in $v i t r o^{42}$, with results supporting a dose-related effect. Nur Atikah et al..$^{43}$ did not observe changes in Fibrobacter succinogenes or Ruminococcus spp. numbers following addition (6\%) of either olive or sunflower oil to high-concentrate diets fed to goats. Similar results (lack of effects on rumen microbiota) were reported in vitro with $3 \%$ soybean oil supplementation in RUSITEC ${ }^{44,45}$. Other microbial groups that are involved in fiber degradation (ciliate protozoa and fungi) were not consistently affected by the vegetable oils. Changes in the bacterial community were reflected in the fermentation end-products profile. Thus, total VFA and acetate were not affected, but propionate increased leading to reduced acetate to propionate ratio in agreement with previous reports ${ }^{46-48}$. Decrease in butyrate output in response to supplementation of all oil types was in agreement with other studies ${ }^{46,49}$ and most likely due to the high sensitivity of butyrate-producing bacteria to polyunsaturated fatty acids ${ }^{22}$. Finally, the supplemental oils reduced the daily ammonia output with no effects on microbial protein synthesis. Similar effects have been reported by other authors ${ }^{16,50}$. The effects of fats on protein degradation and synthesis of microbial protein in the rumen may be affected by the type of diet fermented and by the persistence of ciliate protozoa in the RUSITEC fermenters ${ }^{51,52}$. The reduction in ammonia output in the rumen by the addition of dietary oils could be environmentally beneficial decreasing the emissions of $\mathrm{N}$ from ruminants. These emissions contribute to environmental pollution mainly through the leaching to surface and ground water resources ${ }^{53,54}$. There are, however, contrasting results showing that with some oils the beneficial effect decreasing methane may be traded-off with an increased $\mathrm{N}$ excretion ${ }^{55,56}$.

Daily methane produced (per unit of fermented OM) from ruminal fermentation was decreased by more than $20 \%$ when the basal diet was supplemented with any of the plant oils examined. The depressing effect of supplemental plant oils on methanogenesis cannot be attributed to a general inhibitory effect on ruminal fermentation, as the indicators of the extent of degradation (dietary OM rumen digestibility, production of fermentation gas or daily VFA output) were not affected by any of the supplemental plant oils ${ }^{7}$. Additionally, not only the total daily amount of methane generated was reduced, but also the concentration of methane in the fermentation gas, reinforcing the idea that supplemental plant oils may exert a rather specific effect on methanogenesis. Decreasing methane production in the rumen in response to the addition of oils to the diet without affecting rumen fermentation has been reported by other authors ${ }^{45,57,58}$, and confirmed in meta-analyses pooling data from different studies $^{39,59}$. In agreement with Jalč et al.$^{60}$, this effect was similar regardless the fatty acid composition of the plant oil added. The dietary addition of $\mathrm{C} 18$ free fatty acids decreases methane production from ruminal fermentation, and the extent of this decrease is affected by the degree of fatty acid unsaturation, the inclusion level and the basal $\operatorname{diet}^{57,61}$. When oils or oilseeds differing in their fatty acid (mostly esterified) composition are used as dietary lipid supplements, most of them decrease methane production, with minor differences among the diverse oils or oilseeds $s^{49,62-64}$. Differences among supplemental oils in their effect on ruminal methane production are highly 


\begin{tabular}{|c|c|c|c|c|c|c|c|}
\hline Item & $\begin{array}{l}\text { Control } \\
\text { (CTR) }\end{array}$ & $\begin{array}{l}\text { Olive oil } \\
\text { (OLV) }\end{array}$ & \begin{tabular}{|l|}
$\begin{array}{l}\text { Sunflower oil } \\
\text { (SFL) }\end{array}$ \\
\end{tabular} & $\begin{array}{l}\text { Linseed } \\
\text { oil (LNS) }\end{array}$ & $\begin{array}{l}\text { SEM } \\
(n=4)\end{array}$ & $P$ value & $\begin{array}{l}P \text { value contrast } \\
\text { CTR vs OIL }\end{array}$ \\
\hline \multicolumn{8}{|l|}{ Starch } \\
\hline Asymptotic gas production, $\mathrm{mL} / \mathrm{g}$ & 311 & 310 & 301 & 306 & 17.6 & 0.947 & 0.742 \\
\hline Fractional fermentation rate, $\mathrm{h}^{-1}$ & $0.059^{\mathrm{a}}$ & $0.043^{\mathrm{b}}$ & $0.039^{\mathrm{b}}$ & $0.039^{\mathrm{b}}$ & 0.0036 & 0.001 & $<0.001$ \\
\hline Lag time, $\mathrm{h}$ & $4.6^{\mathrm{a}}$ & $2.1^{\mathrm{b}}$ & $2.2^{\mathrm{b}}$ & $2.4^{\mathrm{b}}$ & 0.44 & $<0.001$ & $<0.001$ \\
\hline Gas production at $24 \mathrm{~h}, \mathrm{~mL} / \mathrm{g}$ & $210^{\mathrm{a}}$ & $191^{\mathrm{b}}$ & $171^{c}$ & $172^{c}$ & 6.1 & $<0.001$ & $<0.001$ \\
\hline Average fermentation rate, $\mathrm{mL} / \mathrm{h}$ & $9.44^{\mathrm{a}}$ & $8.62^{\mathrm{ab}}$ & $7.48^{\mathrm{ab}}$ & $7.50^{\mathrm{b}}$ & 0.350 & 0.037 & 0.091 \\
\hline \multicolumn{8}{|l|}{ Cellulose } \\
\hline Asymptotic gas production, $\mathrm{mL} / \mathrm{g}$ & $352^{\mathrm{a}}$ & $300^{\mathrm{ab}}$ & $278^{\mathrm{b}}$ & $271^{\mathrm{b}}$ & 19.1 & 0.005 & 0.001 \\
\hline Fractional fermentation rate, $\mathrm{h}^{-1}$ & 0.018 & 0.017 & 0.016 & 0.014 & 0.0017 & 0.192 & 0.111 \\
\hline Lag time, $\mathrm{h}$ & 9.8 & 13.7 & 16.7 & 15.2 & 2.64 & 0.112 & 0.030 \\
\hline Gas production at $24 \mathrm{~h}, \mathrm{~mL} / \mathrm{g}$ & $108^{\mathrm{a}}$ & $68^{\mathrm{b}}$ & $52^{\mathrm{b}}$ & $49^{\mathrm{b}}$ & 7.9 & $<0.001$ & $<0.001$ \\
\hline Average fermentation rate, $\mathrm{mL} / \mathrm{h}$ & $3.69^{\mathrm{a}}$ & $2.70^{\mathrm{b}}$ & $2.34^{\mathrm{b}}$ & $2.11^{\mathrm{b}}$ & 0.195 & $<0.001$ & $<0.001$ \\
\hline
\end{tabular}

Table 3. Effects of oils added to the diet RUSITEC fermenters on fermentation kinetics of starch and cellulose in batch cultures. CTR $=$ Control diet; OLV $=$ control diet supplemented with $6 \%$ olive oil; SFL $=$ control diet supplemented with $6 \%$ sunflower oil; LNS $=$ control diet supplemented with $6 \%$ linseed oil. SEM $=$ standard error of the mean. Contrast CTR vs OIL: comparison between CTR and all treatments supplemented with oil. ${ }^{\mathrm{a}, \mathrm{b}}$ Within a row, mean values without common superscript letters differ $(P<0.05)$.

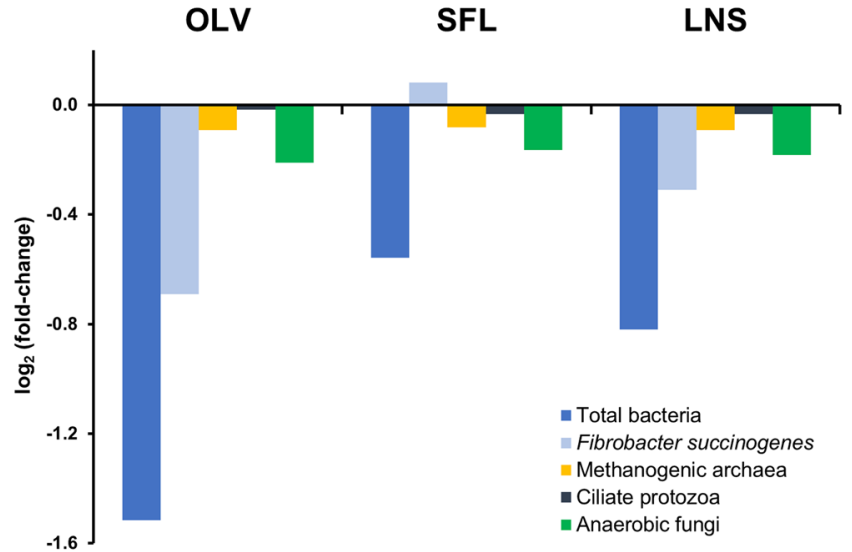

Figure 1. Relative quantitation compared to control diet of copy numbers of rumen microbial groups (major prokaryotic and eukaryotic domains including the methanogen mcrA involved in methanogenesis) after supplementation with olive (OLV), sunflower (SFL) or linseed (LNS) oil. Fold-changes for specific amplicon groups were calculated as the $(\log 2)$ ratio of normalized copy numbers.

dependent on the basal diet, and it seems that the extent of the decrease in methane caused by the addition of different oils is similar when added to a high-concentrate diet $^{33,63}$, as that used in our study. Although the daily output of VFA was not affected by oils, a shift in the fermentation pattern became apparent with a decreased acetate to propionate ratio, in agreement with other authors ${ }^{44,45}$. With the formation of more propionate less $\mathrm{H}_{2}$ would be available for methanogenesis ${ }^{65}$. The inhibitory effects of fats on rumen methanogenesis have been explained also considering the changes in the rumen microbiota, as more dietary oils have been associated to a reduction of ciliate protozoa and methanogen archaea in the rumen ${ }^{9,17,18,66}$. Methanogenic archaea use the available hydrogen in the rumen for methane production ${ }^{1}$. However, Nur Atikah et al..$^{43}$ observed increased methanogen numbers in response to the addition of OLV or SFL oils. In our study, the relative numbers of protozoa and methanogen $m c r A$ were not affected by oil supplementation. However, ciliate protozoa numbers are not sustainable in RUSITEC fermenters ${ }^{67}$. As for methanogenic archaea, it is noteworthy that the copy number of the functional gene $m c r A$ involved in the methanogenesis was quantified by PCR. The quantification of particular groups of methanogens of interest by specific primers targeting specific $16 \mathrm{~S}$ rRNA genes would have provided some valuable additional information ${ }^{68-70}$. Biohydrogenation of unsaturated fatty acids can compete with methanogenesis for metabolic $\mathrm{H}_{2}{ }^{18}$. It can be expected that considerable amounts of $\mathrm{H}_{2}$ will be used for the saturation of fatty acids provided with the oil supplemented diets ${ }^{71}$, and thus diverted from methanogenesis.

In conclusion, the supplementation of ruminant diets with plant oils, in particular from sunflower or linseed, causes some favorable effects on ruminal fermentation. Methane production in the rumen is reduced by adding vegetable oils to high concentrate mixed rations. Concomitantly, ruminal fermentation is altered with a shift towards more propionate production, without affecting the extent of digestion of feed. No substantial differences are observed among vegetable oils (olive, sunflower or linseed) differing in their polyunsaturated fatty acid composition. 
The supplemental oils seem to decrease also the output of ammonia from protein degradation, although it seems necessary to evaluate how dietary strategies influence both $\mathrm{N}$ excretion and methane emissions in ruminants. Considering the observed reduction in methane production, it is possible to propose the addition of plant oils to ruminant rations as a feasible and relatively inexpensive nutritional strategy with a cleaner repercussion on the environment. In this way, the addition of vegetable oils lipids to ruminant diets can improve feed efficiency and attenuate the environmental impact of ruminal fermentation contributing to more efficient, sustainable and cleaner animal production systems, although these effects need to be confirmed under field in vivo conditions.

\section{Methods}

Experimental design. Ruminal fermentation was simulated in vitro using semi-continuous flow fermenters (RUSITEC) for the culture of mixed ruminal microorganisms ${ }^{30}$. The study was designed to investigate the effects of supplementing a high concentrate diet with vegetable oils differing in their fatty acid composition, for a total of four experimental treatments (diets). The control diet (CTR) was a standard high-concentrate total mixed ration for ewes during lactation, and had no supplemental oil (Table 1). Three vegetable oil treatments were prepared by supplementing the control diet with either olive oil (OLV), sunflower oil (SFL) or linseed oil (LNS) in all cases at a concentration of $60 \mathrm{~g} / \mathrm{kg}(6 \%)$ (Table 1). Two RUSITEC systems, each with eight fermentation units, were used having four fermenters (two in each RUSITEC system) for each experimental diet. The experiment followed a randomized complete block design, with four experimental treatments (diets) allocated in two blocks (RUSITEC systems). The experimental unit was each fermentation vessel, resulting in four replicates per treatment.

Procedures, sampling and measurements. Rumen digesta obtained from four sheep fed a diet with $70 \%$ grass hay and $30 \%$ concentrate was used to inoculate the RUSITEC fermenters ${ }^{45}$. Sheep care and handling were in accordance with the principles of the EU Directive 2010/63 on the protection of animals used for specific purposes. The Animal Ethics Committees of CSIC and University of Leon (Spain) had approved the procedures for digesta sampling from sheep. Each fermenter was operated daily as described in detail by García-González et al. ${ }^{72}$ and Vargas et al. ${ }^{45}$. Artificial saliva ( $\mathrm{pH} 8.4,550 \mathrm{~mL} /$ day) was continuously infused to each vessel and incubation temperature was set at $39^{\circ} \mathrm{C}$. Steady state was achieved after 6 -days and thus measurements and samplings were initiated afterwards. Feed ( $15 \mathrm{~g}$ of one of the experimental diets) was provided inside nylon bags $(100 \mu \mathrm{m}$ pore size) placed into a holed plastic container introduced into each fermentation vessel. Bags were withdrawn after $48 \mathrm{~h}$ of incubation and replaced with others providing feed. The undigested residue remaining in the bags after $48 \mathrm{~h}$ was used to calculate the diet digestibility (as matter disappearance from the bag) in the rumen. The liquid flowing out the vessel (effluent) was collected in conical flasks, and a sample (50 mL) was collected daily and frozen $\left(-18^{\circ} \mathrm{C}\right)$ for ammonia and VFA analysis. Fermentation gas was collected in airtight bags, volume of gas produced daily was measured using a flow meter, and samples of gas were taken in hermetic vacuum glass tubes. All these samples (incubation residues, effluent and gas) were collected on days 7, 8, 9, 14, 15 and 16 of the experiment, and the values recorded were averaged across the six measurement days for each vessel.

A representative sample of total digesta (effluent + bag residue) was collected on day 12 after infusing $\left({ }^{15} \mathrm{NH}_{4}\right) \mathrm{SO}_{4}$ into the vessels for three days ${ }^{45}$. A microbial pellet was isolated from this sample and microbial protein output from each vessel was determined using ${ }^{15} \mathrm{~N}$ as a marker as described by Carro and Miller ${ }^{73}$. On day 17, samples of digesta were obtained by mixing liquid content with bag residues from each vessel, frozen at $-80^{\circ} \mathrm{C}$ and freeze-dried. DNA was extracted from these latter samples and then used for quantitative real-time polymerase chain reaction (qPCR) to quantitate the abundance of some key microbial groups ${ }^{45}$.

Fermentation kinetics of pure substrates (starch or cellulose) were determined using the in vitro gas production technique ${ }^{74}$, and the procedures described in detail by Vargas et al. ${ }^{45}$. Once the RUSITEC study was finished, the liquid contents of each fermenter were used as inoculum for batch cultures incubated in 120 -mL serum bottles. In each bottle $500 \mathrm{mg}$ of each substrate were weighed and mixed with $50 \mathrm{~mL}$ of fluid from each RUSITEC vessel. The bottles were sealed and incubated at $39^{\circ} \mathrm{C}$, measuring the volume of fermentation gas released to the headspace by using a pressure transducer. Gas measurements were recorded at different time intervals from inoculation to $92 \mathrm{~h}$ of incubation ${ }^{45}$, building up a curve plotting cumulative gas production against incubation time. Fermentation kinetics (extent and rate of degradation of each substrate) were derived by fitting the exponential model of France et al..$^{75}$ to each gas production curve. As for each substrate the only difference was the inoculum used for the cultures, the fermentation kinetics were assumed to characterize the amylolytic or cellulolytic activity in each RUSITEC vessel as affected by its diet (unsupplemented or supplemented with any of the plant oils).

Chemical and qPCR analyses. Analytical methods for the determination of chemical composition (proximate analyses), VFA in effluent and methane in fermentation gas (gas chromatography), ammonia nitrogen in effluent (colorimetry), and non-ammonia $\mathrm{N}$ and ${ }^{15} \mathrm{~N}$ enrichment in digesta and microbial pellets (isotope ratio mass spectrometry) were described in detail by García-González et al. ${ }^{72}$. Fatty acids in oils and diets were determined according to Morán et al. ${ }^{76}$.

Real-time PCR was carried out using the procedures and primers detailed by Vargas et al. ${ }^{45}$ for the quantitative estimation of copy numbers of bacteria, Fibrobacter succinogenes, ciliate protozoa, fungi and methanogenic archaea in the digesta samples collected from each vessel at the end of the study. Standards for PCR quantitation of each microbial group were obtained from plasmids in which the specific PCR amplicon sequence had been inserted ${ }^{40}$.

Statistical analysis. Data were subjected to ANOVA using the SAS software package (SAS Institute Inc. 2011. SAS/STAT ${ }^{\circledR} 9.3$ User's Guide. Cary, NC: SAS Institute Inc.). The statistical model included three sources of variability namely the fixed effect of diet (CTR, OLV, SFL or LNS), the blocking factor (RUSITEC system 1 or 2) and the residual error. The Tukey test was used for the multiple comparisons of means, and the effect of adding any vegetable oil to the diet was tested by an orthogonal contrast. 
Received: 12 September 2019; Accepted: 14 January 2020; Published online: 31 January 2020

\section{References}

1. Huws, S. A. et al. Addressing global ruminant agricultural challenges through understanding the rumen microbiome: past, present, and future. Front. Microbiol. 9, 2161, https://doi.org/10.3389/fmicb.2018.02161 (2018).

2. McSweeney, C. \& Mackie, R. Micro-organisms and ruminant digestion: State of knowledge, trends and future prospects. Background study paper No. 61. Commission on Genetic Resources for Food and Agriculture, FAO. (2012).

3. Owens, F. N. \& Basalan, M. Ruminal fermentation. In Rumenology (eds. Millen, D. D., Arrigoni, M. D. B. \& Pacheco, R. D. L.) 63-102, https://doi.org/10.1007/978-3-319-30533-2_3 (Springer International Publishing AG, 2016).

4. York, L., Heffernan, C. \& Rymer, C. A systematic review of policy approaches to dairy sector greenhouse gas (GHG) emission reduction. J. Clean. Prod. 172, 2216-2224 (2018).

5. Tullo, E., Finzi, A. \& Guarino, M. Review: Environmental impact of livestock farming and Precision Livestock Farming as a mitigation strategy. Sci. Total Environ. 650, 2751-2760 (2019).

6. Moumen, A., Azizi, G., Chekroun, K. B. \& Baghour, M. The effects of livestock methane emission on the global warming: a review. Int. J. Global Warm. 9, 229-253 (2016).

7. Patra, A. K. Recent advances in measurement and dietary mitigation of enteric methane emissions in ruminants. Front. Vet. Sci. 3, 39, https://doi.org/10.3389/fvets.2016.00039 (2016).

8. Morgavi, D. P., Forano, E., Martin, C. \& Newbold, C. J. Microbial ecosystem and methanogenesis in ruminants. Animal 4, 1024-1036 (2010).

9. Hook, S. E., Wright, A.-D. G. \& McBride, B. W. Methanogens: methane producers of the rumen and mitigation strategies. Archaea 2010, 945785 , https://doi.org/10.1155/2010/945785 (2010).

10. Bodas, R. et al. Manipulation of rumen fermentation and methane production with plant secondary metabolites. Anim. Feed Sci. Technol. 176, 78-93 (2012).

11. Ugbogu, E. A. et al. The potential impacts of dietary plant natural products on the sustainable mitigation of methane emission from livestock farming. J. Clean. Prod. 213, 915-925 (2019).

12. Hristov, A. N. et al. Mitigation of methane and nitrous oxide emissions from animal operations: I. A review of enteric methane mitigation options. J. Anim. Sci. 91, 5045-5069 (2013).

13. Bayat, A. R., Tapio, I., Vilkki, J., Shingfield, K. J. \& Leskinen, H. Plant oil supplements reduce methane emissions and improve milk fatty acid composition in dairy cows fed grass silage-based diets without affecting milk yield. J. Dairy Sci. 101, 1136-1151 (2017).

14. Knapp, J. R., Laur, G. L., Vadas, P. A., Weiss, W. P. \& Tricarico, J. M. Enteric methane in dairy cattle production: Quantifying the opportunities and impact of reducing emissions. J. Dairy Sci. 97, 3231-3261 (2014).

15. Martin, C., Morgavi, D. P. \& Doreau, M. Methane mitigation in ruminants: from microbe to the farm scale. Animal 4, 351-365 (2010).

16. Beauchemin, K. A., McGinn, S. M. \& Petit, H. V. Methane abatement strategies for cattle: Lipid supplementation of diets. Can. J. Anim. Sci. 87, 431-440 (2007).

17. Patra, A., Park, T., Kim, M. \& Yu, Z. Rumen methanogens and mitigation of methane emission by anti-methanogenic compounds and substances. J. Anim. Sci. Biotechnol. 8, 13, https://doi.org/10.1186/s40104-017-0145-9 (2017).

18. Toprak, N. N. Do fats reduce methane emission by ruminants? - a review. Anim. Sci. Pap. Rep. 33, 305-321 (2015).

19. Tapio, I., Snelling, T. J., Strozzi, F. \& Wallace, R. J. The ruminal microbiome associated with methane emissions from ruminant livestock. J. Anim. Sci. Biotechnol. 8, 7, https://doi.org/10.1186/s40104-017-0141-0 (2017).

20. McAllister, T. A. et al. Effect of exogenous enzymes on digestibility of barley silage and growth performance of feedlot cattle. Can. J. Anim. Sci. 79, 353-360 (1999).

21. Nagaraja, T. G., Newbold, C. J., van Nevel, C. J. \& Demeyer, D. I. Manipulation of ruminal fermentation in The rumen microbial ecosystem (eds. Hobson, P. N. \& Stewart, C. S.) 523-632, https://doi.org/10.1007/978-94-009-1453-7_13 (Springer, 1997).

22. Maia, M. R. G., Chaudhary, L. C., Figueres, L. \& Wallace, R. J. Metabolism of polyunsaturated fatty acids and their toxicity to the microflora of the rumen. Antonie Van Leeuwenhoek 91, 303-314 (2007).

23. Jenkins, T. C. Lipid metabolism in the rumen. J. Dairy Sci. 76, 3851-3863 (1993).

24. Stewart, C. S. Factors affecting the cellulolytic activity of rumen contents. Appl. Environ. Microbiol. 33, 497-502 (1977).

25. Harvatine, K. J. \& Allen, M. S. Effects of fatty acid supplements on ruminal and total tract nutrient digestion in lactating dairy cows. J. Dairy Sci. 89, 1092-1103 (2006).

26. Martínez Marín, A. L., Pérez Hernández, M., Pérez, A., Gómez Castro, G. L. \& Carrión Pardo, D. Efecto de las fuentes de grasa sobre la digestión de la fibra en los rumiantes. Rev. Electron. Vet. 12, 1-22 (2011).

27. Palmquist, D. L. \& Jenkins, T. C. Fat in lactation rations: Review. J. Dairy Sci. 63, 1-14 (1980).

28. Weld, K. A. \& Armentano, L. E. The effects of adding fat to diets of lactating dairy cows on total-tract neutral detergent fiber digestibility: A meta-analysis. J. Dairy Sci. 100, 1766-1779 (2017).

29. Edwards, J. E. et al. Advances in microbial ecosystem concepts and their consequences for ruminant agriculture. Animal 2, 653-660 (2008).

30. Czerkawski, J. W. \& Breckenridge, G. Design and development of a long-term rumen simulation technique (Rusitec). Br. J. Nutr. 38, 371-384 (1977)

31. Fievez, V., Vlaeminck, B., Jenkins, T., Enjalbert, F. \& Doreau, M. Assessing rumen biohydrogenation and its manipulation in vivo, in vitro and in situ. Eur. J. Lipid Sci. Technol. 109, 740-756 (2007).

32. Jenkins, T. C. Effect of fats and fatty acid combinations on ruminal fermentation in semi-continuous in vitro cultures. J. Anim. Sci. 64, 1526-1532 (1987).

33. Dong, Y., Bae, H. D., McAllister, T. A., Mathison, G. W. \& Cheng, K.-J. Lipid-induced depression of methane production and digestibility in the artificial rumen system (RUSITEC). Can. J. Anim. Sci. 77, 269-278 (1997).

34. Ueda, K. et al. Effect of linseed oil supplementation on ruminal digestion in dairy cows fed diets with different forage:concentrate ratios. J. Dairy Sci. 86, 3999-4007 (2003).

35. Doreau, M. \& Ferlay, A. Effect of dietary lipids on nitrogen metabolism in the rumen: a review. Livest. Prod. Sci. 43, 97-110 (1995).

36. Candyrine, S. C. L. et al. In vitro rumen fermentation characteristics of goat and sheep supplemented with polyunsaturated fatty acids. Anim. Prod. Sci. 57, 1607 (2017).

37. Doreau, M., Aurousseau, E. \& Martin, C. Effects of linseed lipids fed as rolled seeds, extruded seeds or oil on organic matter and crude protein digestion in cows. Anim. Feed Sci. Technol. 150, 187-196 (2009).

38. Hess, B. W., Moss, G. E. \& Rule, D. C. A decade of developments in the area of fat supplementation research with beef cattle and sheep. J. Anim. Sci. 86, E188-E204 (2008).

39. Patra, A. K. A meta-analysis of the effect of dietary fat on enteric methane production, digestibility and rumen fermentation in sheep, and a comparison of these responses between cattle and sheep. Livest. Sci. 162, 97-103 (2014).

40. Andrés, S. et al. Effects of the inclusion of flaxseed and quercetin in the diet of fattening lambs on ruminal microbiota, in vitro fermentation and biohydrogenation of fatty acids. J. Agric. Sci. 154, 542-552 (2016). 
41. Vargas-Bello-Pérez, E., Cancino-Padilla, N., Romero, J. \& Garnsworthy, P. C. Quantitative analysis of ruminal bacterial populations involved in lipid metabolism in dairy cows fed different vegetable oils. Animal 10, 1821-1828 (2016).

42. Maia, M. R. et al. Toxicity of unsaturated fatty acids to the biohydrogenating ruminal bacterium, Butyrivibrio fibrisolvens. BMC Microbiol. 10, 52, https://doi.org/10.1186/1471-2180-10-52 (2010).

43. Nur Atikah, I. et al. Profiling of rumen fermentation, microbial population and digestibility in goats fed with dietary oils containing different fatty acids. BMC Vet. Res. 14, 344, https://doi.org/10.1186/s12917-018-1672-0 (2018).

44. Potu, R. B., AbuGhazaleh, A. A., Hastings, D., Jones, K. \& Ibrahim, S. A. The effect of lipid supplements on ruminal bacteria in continuous culture fermenters varies with the fatty acid composition. J. Microbiol. 49, 216-223 (2011).

45. Vargas, J. E. et al. Effect of sunflower and marine oils on ruminal microbiota, in vitro fermentation and digesta fatty acid profile. Front. Microbiol. 8, 1124, https://doi.org/10.3389/fmicb.2017.01124 (2017).

46. Chalupa, W., Rickabaugh, B., Kronfeld, D. \& David Sklan, S. Rumen fermentation in vitro as influenced by long chain fatty acids. J. Dairy Sci. 67, 1439-1444 (1984).

47. Jalč, D., Potkański, A., Szumacher-Strabel, M., Kowalczyk, J. \& Cieślak, A. The effect of a high concentrate diet and different fat sources on rumen fermentation in vitro. J. Anim. Feed Sci. 15, 137-140 (2006).

48. Jalč, D., Potkański, A., Szumacher-Strabel, M., Kowalczyk, J. \& Cieślak, A. The effect of a forage diet and different fat sources on rumen fermentation in vitro. J. Anim. Feed Sci. 15, 129-132 (2006).

49. Machmüller, A., Ossowski, D., Wanner, M. \& Kreuzer, M. Potential of various fatty feeds to reduce methane release from rumen fermentation in vitro (Rusitec). Anim. Feed Sci. Technol. 71, 117-130 (1998).

50. Schmidely, P., Glasser, F., Doreau, M. \& Sauvant, D. Digestion of fatty acids in ruminants: a meta-analysis of flows and variation factors. 1. Total fatty acids. Animal 2, 677-690 (2008).

51. Broudiscou, L. \& Lassalas, B. Linseed oil supplementation of the diet of sheep: effect on the in vitro fermentation of amino acids and proteins by rumen microorganisms. Anim. Feed Sci. Technol. 33, 161-171 (1991).

52. Oldick, B. S. \& Firkins, J. L. Effects of degree of fat saturation on fiber digestion and microbial protein synthesis when diets are fed twelve times daily. J. Anim. Sci. 78, 2412-20 (2000).

53. Kebreab, E., France, J., Beever, D. E. \& Castillo, A. R. Nitrogen pollution by dairy cows and its mitigation by dietary manipulation. Nutr. Cycl. Agroecosys. 60, 275-285 (2001).

54. Dijkstra, J., Bannink, A., Bosma, P. M., Lantinga, E. A. \& Reijs, J. W. Modeling the effect of nutritional strategies for dairy cows on the composition of excreta nitrogen. Front. Sustain. Food Syst. 2, 63, https://doi.org/10.3389/fsufs.2018.00063 (2018).

55. Dijkstra, J., Oenema, O. \& Bannink, A. Dietary strategies to reducing N excretion from cattle: Implications for methane emissions. Curr. Opin. Environ. Sustain. 3, 414-422 (2011).

56. Muñoz, C. et al. Effects of feeding unprocessed oilseeds on methane emission, nitrogen utilization efficiency and milk fatty acid profile of lactating dairy cows. Anim. Feed Sci. Technol. 249, 18-30 (2019).

57. Zhang, C. M. et al. Effect of octadeca carbon fatty acids on microbial fermentation, methanogenesis and microbial flora in vitro. Anim. Feed Sci. Technol. 146, 259-269 (2008).

58. Castagnino, P. S. et al. Glycerol combined with oils did not limit biohydrogenation of unsaturated fatty acid but reduced methane production in vitro. Anim. Feed Sci. Technol. 201, 14-24 (2015).

59. Eugène, M., Massé, D., Chiquette, J. \& Benchaar, C. Meta-analysis on the effects of lipid supplementation on methane production in lactating dairy cows. Can. J. Anim. Sci. 88, 331-337 (2008).

60. Jalč, D., Cieślak, A., Szumacher-Strabel, M., Potkański, A. \& Kowalczyk, J. The effect of different oils and diets on methane release in an artificial rumen (Rusitec). J. Anim. Feed Sci. 15, 149-152 (2006).

61. Jalč, D., Čertík, M., Kundríková, K. \& Náměstková, P. Effect of unsaturated C18 fatty acids (oleic, linoleic and $\alpha$-linolenic acids) on ruminal fermentation and production of fatty acids isomers in artificial rumen. Vet. Med. (Praha). 52, 87-94 (2008).

62. Kubelková, P., Jalč, D., Jančík, F. \& Homolka, P. In vitro ruminal fermentation and fatty acid production by various oil seeds. S. Afr. J. Anim. Sci. 48, 526-534 (2018).

63. Szumacher-Strabel, M., Martin, S., Potkański, A., Cieślak, A. \& Kowalczyk, J. Changes in fermentation processes as the effect of vegetable oil supplementation in in vitro studies. J. Anim. Feed Sci. 13, 215-218 (2004).

64. Jalč, D. \& Čerešňáková, Z. Effect of plant oils and malate on rumen fermentation in vitro. Czech J. Anim. Sci. 47, 106-111 (2002).

65. Hegarty, R. S. Mechanisms for competitively reducing ruminal methanogenesis. Aust. J. Agric. Res. 50, 1299-1306 (1999).

66. Broucek, J. Options to methane production abatement in ruminants: a review. J. Anim. Plant Sci. 28, 348-364 (2018).

67. Martínez, M. E., Ranilla, M. J., Tejido, M. L., Saro, C. \& Carro, M. D. Comparison of fermentation of diets of variable composition and microbial populations in the rumen of sheep and Rusitec fermenters. II. Protozoa population and diversity of bacterial communities. J. Dairy Sci. 93, 3699-3712 (2010).

68. Snelling, T. J. et al. Diversity and community composition of methanogenic archaea in the rumen of Scottish Upland sheep assessed by different methods. PLoS One 9, e106491, https://doi.org/10.1371/journal.pone.0106491 (2014).

69. Narihiro, T. \& Sekiguchi, Y. Oligonucleotide primers, probes and molecular methods for the environmental monitoring of methanogenic archaea. Microb. Biotechnol. 4, 585-602 (2011).

70. Skillman, L. C., Evans, P. N., Strompl, C. \& Joblin, K. N. 16S rDNA directed PCR primers and detection of methanogens in the bovine rumen. Lett. Appl. Microbiol. 42, 222-228 (2006).

71. Vargas, J. E., Andrés, S., López-Ferreras, L. \& López, S. Effects of supplemental plant oils on rumen bacterial community profile and digesta fatty acid composition in a continuous culture system (RUSITEC). Anaerobe 61, 102143, https://doi.org/10.1016/j. anaerobe.2019.102143 (2020).

72. García-González, R., González, J. S. \& López, S. Decrease of ruminal methane production in Rusitec fermenters through the addition of plant material from rhubarb (Rheum spp.) and alder buckthorn (Frangula alnus). J. Dairy Sci. 93, 3755-3763 (2010).

73. Carro, M. D. \& Miller, E. L. Effect of supplementing a fibre basal diet with different nitrogen forms on ruminal fermentation and microbial growth in an in vitro semi-continuous culture system (RUSITEC). Br. J. Nutr. 82, 149 (1999).

74. Theodorou, M. K., Williams, B. A., Dhanoa, M. S., McAllan, A. B. \& France, J. A simple gas production method using a pressure transducer to determine the fermentation kinetics of ruminant feeds. Anim. Feed Sci. Technol. 48, 185-197 (1994).

75. France, J., Dijkstra, J., Dhanoa, M. S. S., López, S. \& Bannink, A. Estimating the extent of degradation of ruminant feeds from a description of their gas production profiles observed in vitro: derivation of models and other mathematical considerations. Br. J. Nutr. 83, 143-150 (2000).

76. Morán, L. et al. Effect of dietary carnosic acid on the fatty acid profile and flavour stability of meat from fattening lambs. Food Chem. 138, 2407-2414 (2013).

\section{Acknowledgements}

This work was supported by the Consejería de Educación, Junta de Castilla y León (research project LE007A07); and the Government of Spain (CICYT project AGL2005-04760-C02-02). 


\section{Author contributions}

S.L. and S.A. conceived of and designed the experiments. J.E.V. and S.L. (RUSITEC experiments, sampling), L.L.-F. (qPCR), and C.G.-E. (DNA analysis) performed the experiments. S.L., S.A., J.E.V., T.J.S. and D.R.Y.-R. analysed the data. The manuscript was written by J.E.V., T.J.S., S.A. and S.L., and all authors contributed to refining the text and approved the version to be submitted.

\section{Competing interests}

The authors declare no competing interests.

\section{Additional information}

Correspondence and requests for materials should be addressed to S.L.

Reprints and permissions information is available at www.nature.com/reprints.

Publisher's note Springer Nature remains neutral with regard to jurisdictional claims in published maps and institutional affiliations.

(c) (1) Open Access This article is licensed under a Creative Commons Attribution 4.0 International License, which permits use, sharing, adaptation, distribution and reproduction in any medium or format, as long as you give appropriate credit to the original author(s) and the source, provide a link to the Creative Commons license, and indicate if changes were made. The images or other third party material in this article are included in the article's Creative Commons license, unless indicated otherwise in a credit line to the material. If material is not included in the article's Creative Commons license and your intended use is not permitted by statutory regulation or exceeds the permitted use, you will need to obtain permission directly from the copyright holder. To view a copy of this license, visit http://creativecommons.org/licenses/by/4.0/.

(c) The Author(s) 2020 